\title{
Recognition of Pantang Larang on Children in West Borneo Coastal Malayan Myth (Indonesia) Through Digital Storytelling
}

\author{
${ }^{1}$ Sri Kusnita, ${ }^{2}$ Sarwiji Suwandi, ${ }^{3}$ Muhammad Rohmadi, ${ }^{4}$ Nugraheni Eko Wardani \\ ${ }^{1}$ srikusnitahidayat@student.uns.ac.id, ${ }^{2}$ sarwijiswan@yahoo.com, ${ }^{3}$ rohmadi_dhe@ yahoo.com, \\ ${ }^{4}$ nugraheniekowarnadi_99@yahoo.co.id
}

Universitas Sebelas Maret, Surakarta Indonesia

\begin{abstract}
Communication technology especially the application of digital storytelling is necessary to be developed. Digital storytelling is a kind of strategy in telling story which uses computer application so that it will attract children's interest to listen and to read the Folklore which is packed in the form of digital storytelling, because it is equipped with audio, pictures, music, and text which are packed in such a way which is delivered through digital multimedia. Based on the data analysis, there are five pantang larang in Coastal Malaysian myth in West Borneo, including: 1) pantang larang when entering a forest, 2) going out of the house when hot rain, 3) laughing at a cat when it is raining, 4) rejecting invitation for having a meal, and 5) cutting down Jawi-Jawi trees and killing crocodiles. These pantang larang have a function as a mean to educate children to obey their family, cherish others, and love nature. Next, pantang larang also has a meaning for society in order that children have attitudes of discipline, respectful, sharing with others, and do not destroy nature. The society of Coastal Malaysian in West Borneo assumes that pantang larang has a special position.
\end{abstract}

Keywords: pantang larang, folklore, Communication Technology

\section{Introduction}

Malaysian oral literature is a kind of media in delivering thought and way of life of Malaysian people [1]. One of the various oral literatures owned by Malaysian people is folklore. Bronner [2] states that "folklore is an instructional insight because folklore contents some cultural and wisdom knowledge which is derived from generations, which origins from the previous society". Besides that, folklore has various forms or categories. According to Normaliza [3] the categories of "Malays folklore is grouped into some stories, including (1) legend which tells about the history and the origin of a place, name, or thing; (2) myth, (3) fable, etc." Zafar and Sandhu [4] states, "Narrative oral literature is classified into fairytale, myth, anecdote, ballad, and other oral stories." This study focuses on pantang larang study which is covered in Coastal Malaysian myth in West Borneo.

Myth is a kind of folklore which always appears in various societies' social religious activity, especially on traditional society and almost always there in every culture. Khabibullina and Zinnatullina [5] explain that myth is a product of collective imagination which consists of images that show off the societies' representation about self and mentality of the societies. According to Jaja [6], "Myth is a kind of story which is believed by its societies that it is really happened." Othman [7] states that, "Myth is a traditional story which tells about historical events which are as though happened known by a part of the world's views or explaining a practice, belief or natural phenomena happened in the past".

People in Indonesia still use some myths on their life. Most people are covered by some myths which have sacred value for their owner, invariably the Coastal Malaysian people in West Borneo. "The Coastal Malaysian people in West Borneo belong to Malaysian ethnic who show 
the same cultural system pattern, such as: (a) Malaysian ethnic of West Borneo is identic with Moslem (b) hereditarily they settle down in the Coastal area of West Borneo (c) psychologically, they feel that they are Malaysian people who use Malaysian Language [8]. Malaysian ethnic in West Borneo assume their selves as Malaysian, who are bound by the same traditions, such as: they are Moslems, using Malaysian Language, using Malaysian customs and their Malaysian moral spirit is Islamic spirit.

The people of Coastal Malaysian in West Borneo occupy some regency including Sambas Regency, Mempawah, Kubu Raya, and Pontianak Municipality. Coastal Malaysian people in West Borneo are rich in myths which contain some hereditary beliefs that have become a part of the regulation of life in the societies. According to Wahab [9], these beliefs and practices are manifested through traditional advices and pantang larang which is believed giving some impact on life. Pantang Larang is a kind of prohibition to do something according to its societies' custom and belief.

Even though they are Moslems, the Coastal Malaysian people in West Borneo still believe on some myths which is in it there is pantang larang as a rule on their life. Othman [7] states that "The arrival of Islam does not make Malay people get to ignore their myth and legendary story. Otherwise, the myth is believed as a real substance especially by the people of Malaysian". According to Mohtar [10], "In the life of Malaysian societies from ancient times until now they still assume strongly pantang larang as their life guide or guidelines. The belief on this pantang larang does not also contradictory to the Islamic tenet". On its development and the influence of pantang larang on their life, Malaysian people have adjusted it in order not to be contradictory with Islamic tenet.

The existence of this belief to pantang larang in Coastal Malaysian myth in West Borneo needs to be maintained because it is a form of cultures owned by Indonesian. Technology advances are able to change the ancestors' culture, thus the pantang larang culture which contains much local wisdom value gets to be abandoned by young generation. If it is left to happen, then it will cause the disappearance of belief to pantang larang, which is basically used as a mean in educating people to maintain their ancestors' customs and values. Ling and Tabitha [11] state that globalization makes modern values, ideas, and views possible to spread quickly which has potential to awaken the power of traditional customs or cultures. Young generation should study and understand the pantang larang which develops in the society. One of the ways which is taken in studying and understanding pantang larang is by carrying out a study. According to Sarmidi [12] patang larang is needed to be inventoried correctly as a form of study material or oral literature study and cultural study especially its existence in regional cultural context with a more sufficient explanation and the possibility of values transformation from some taboo-natured values will become scientific.

The aim of this study is to describe the function and the meaning of pantang larang of Malay societies contained in the myth of Coastal Malay in West Borneo in order that the readers can find out some pantang larang which have developed on Malay societies who have Coastal Malaysian myth in West Borneo. By finding out the function and the meaning of pantang larang it is expected that the society can maintain the sustainability of pantang larang in order not to be forgotten especially by young generation. According to Haryadi and Irwan [13], the rapid technology advances has become a cause why the myth in the society has begun to be forgotten. Parents' attention to their children has decreased, even early age children have been provided with electronic equipment. It makes the communication between parents and their children become increasingly rare which causes the lack of moral values educating through pantang larang on children. Therefore, an introduction of function and meaning of pantang larang through communication technology especially visual communication media by using 
storytelling approach becomes important to be carried out. Technology development is very helpful for people to tell story to their children which can be done through digital media. By the presence of via digital media stories with an interesting display, children can be lingering for just watching folklore movie in the form of animation, reading comic, or reading some stories through laptop, computer, or smartphone. Based on this fact, digital storytelling is very suitable to be used as a media in introducing pantang larang contained in the folklore because it is a strategic step to introduce cultures to young generation.

\section{Literature Review \\ 2.1 Pantang Larang}

Pantang larang is a form of rules which relates to the societies' belief which if it is violated there will be a disaster happened. Besides that, pantang larang is a set of norms which is effective to control people's attitude who support it. According to Ramli and Marinsah [14], pantang larang of Malay people can have a function to keep the harmony of living in a community and is used as a rule in order to avoid from disaster and to prevent something bad happened. Syahrir [15] states that pantang larang has a function for giving advice to children and has a meaning which is related to the religious values, culture, and social norms which exist in society to their next generation. Thus, pantang larang can also be used to direct its society in order to act accordingly to the values present in the society. In the Coastal Malaysian Society, the people have known pantang larang since a long time ago, which is often founded on either their daily oral conversation or oral literature (folklores).

For Malaysian people, pantang larang is a form of oral rules which is inherited from generation to generation. Malaysian people do not ever question about the truth of pantang larang exists in their region. According to Kurniawan [16], Malay people have been conditioned to accept pantang larang as an unwritten rule in their daily lives. Omar [17] states that pantang larang is one form of cultures of Traditional Malaysian societies which inside it there contains various locutions which belong to nation's treasure and based on the life experience in the past. Pantang larang for Malay is their belief related to the customs and cultures of the ancestral heritage.

\subsection{Myth}

Myth always appears in various social religious activity of society, especially in traditional societies and almost presents in every culture. Myth comes from Greek, mythos which means story that is about gods, nature, people or objects which often contain some unseen and sacred things [18]. Myth is considered either really happened or sacred by the owner of the story. Thus, myth belongs to sacred story which supports the belief system or religion. The content of the story in myth is considered sacred by its supporting society because it relates to supernatural life. Danandjaja [19] states that," Myth is fortified by gods or demigod creatures". The happening was happened in other world, not in the world known today and in the past.

The characters (figures) in myth usually have unique talent or supernatural power, so that something which is done by the characters in the story is considered as a sacred legitimated story. Next, this thing will make "myth can be accepted in the society as a story that was really happened in the past [9]. Based on this explanation, it can be said that myth is a signifier of a culture. Through myth, it can be traced the past of a culture in various spiritual feature depictions and ideals of the society which finally will also give message and image to the current generation. Usman and Hasbulah [20] confirm that, "Myth has some role and function in the structure of society". This function attaches either individually or collectively. In the social construction of traditional society, myth has become a fastener of cultural values, social moral 
and norm on its structure, so that it will expose the constituent of values and ideal living rules in society.

Myth usually gives some influences to various rules which are often related to the reality of life. Therefore, myth is a model of paradigm about what is happened, myth gives some examples which can be used for references in people's act and attitude. At the arkhais culture level, every activity done by human being has a nearly same model with adi-manusiawi, that is model the gods have created [21]. Every people have different belief to the myth. Besides that, myth from the past until now is still believed by the society. Other privilege from myth (folklore) is that it can be used as a guidance or belief for such society as the supporter of the myth [21]. This sense of belief creates a rule which is acted out in the life of its owner society. Myth is also seen as a rational thing and is managed by cause and effect although in different dimension from which presents in modern people.

\subsection{Storytelling}

Storytelling or telling a story is a delivery of event in the form of words, objects and sounds. Some story which has existed in every culture is used as a mean of entertainment, education, culture preservation and nourishing morality values [22]. Furthermore, according to Alimin [23] , Storytelling also gives learning experience by using storytelling technique which enables children to develop their cognitive, affective, and also psychomotor ability. Rahmawati [24] states that telling a story is an activity which is performed verbally or in writing. The way of its delivery can be done by using some properties. Telling a story is also a means in introducing cultural values to children, by using telling story activity parents can educate and shape children's personality appropriate to the prevailed norms in the society.

The aims of telling a story according to Gunarti, Suryani, \& Muis in Rahmawati [24], a) Developing language ability, for example listening, speaking ability, and increasing children's vocabulary. b) Developing ability in thinking because by telling a story, children are invited to focus their attention on the storyline and developing their thinking ability with symbol. c) Instilling moral messages contained in the story. d) Developing children's social sensitivity on something happened around them. e) Developing children's creative potency through the diversity of story idea which is conveyed.

Telling story activity to children has an important role, not only in emerging reading interests and habits but also in developing language ability on children [25]. Furthermore Dhieni at al. [25] also states that the benefits of telling a story for children are: a) training children's absorption power and comprehension power, b) training children's concentration power to focus their mind, c) developing children's imagination power, d) telling a story can give learning experience in order to train listening ability, e) supporting the development of children's language ability in communication, and f) telling a story is used to instill in children honesty, sincerity, truth, and positive attitude. Hariyadi \& Irwan [13] state that the rapid development of technology nowadays has made storytelling activity experiencing a shift, because this activity is not only delivered verbally but it shifts through various forms of communication. The presence of communication technology, especially mobile equipment has changed storytelling paradigm, which is not merely oral utterance but also giving some audio, visual imaging or interaction between the story and children. 


\subsection{Communication Technology (Digital Storytelling)}

The development of technology which becomes more sophisticated makes parents forget storytelling culture to introduce the applicable norms in society. Many people do not deliver some stories which contain values of manner through verbal communication anymore, like something that has been done by the previous society. Nowadays, there are many parents who leave their children watching for video and playing games by using smartphone which provide communication visually. According to Fatmawati [26], the using of technology which is used to arrange and develop learning media for children is perceived very effective. The use of learning media by using visual technology is very important today. It needs to be done in order to attract children's interest to know pantang larang which lives in their society, which has been used to educate by the previous generation. Haryadi \& Irwan [13] states that visual communication media is a kind of communication means which focuses on writing and pictures captured by the sense of sight. Along with the progress of technology, visual communication media becomes more widespread until it changes its form into audio-visual communication that is video, film, animation, interactive media, and games.

The emergence of audio-visual communication has brought a new phenomenon in this digital era that is listening for a story by using digital instrument which is called with digital storytelling. According to Landis et.al. [27], digital storytelling is a form of art which combines some media, including pictures, audio, and video to make a short story. Furthermore, Fatmawati [26] states that storytelling covers storytelling practice by using digital media in multimedia which is produced by the professionals. The intended digital media can be in the form of block narration, social media, interactive narration, game, and animated movie. Digital storytelling is a strategy in telling a story which uses computer application so that it can attract children's interest to listen or to read the story. Through this media, knowledge can be transferred through an interesting story so that the culture of telling a story is not left by the society anymore.

\section{Methodology}

This study uses descriptive qualitative method. Cresswell [28] states that qualitative research is focused on the process happened in the research. Besides that, qualitative research is an important part in understanding social phenomena happened in the process of research. According to Osman [1], qualitative method can be used in in-depth analysis to various literatures. The design of qualitative method has helped in analyzing Oral Malaysian literatures. Qualitative approach is applied in the description of storytelling concept which is related to digital storytelling media in the form of digital story [13]. Source of the data in this study is the myth of Coastal Malay in West Borneo. The location of this study is Sambas, Mempawah, Kubu Raya Regency, and Municipality of Pontianak.

\section{Result and Discussion}

As a belief, pantang larang which is developed in society, its existence has to be maintained in order to maintain the tradition and cultures, likewise for Coastal Malaysian people in West Borneo. Pantang larang which is existed in some myths is a hereditary heritage from the previous generation to the next generation. According to Hamidy [29], pantang larang is an inheritance or their ancestral heritage and they have responsibility to implement and pass down this tradition to their grandchildren. Effendi [30] emphasizes that pantang larang is an act which is beaten based on the traditional belief and is still considered sacred. The analysis of function and meaning of pantang larang in this study is described qualitatively based on the myth story.

Pantang larang which is contained in the myth is not only used to scare people, but it has a purpose to educate and to advise young generation which is delivered as a forbidden deed 
according to the custom. Sefridanita, Nurizzati, and zulfikarni [31] explain that the main function of pantang larang is to deliver the intended message subtly with a purpose not offending others. Another function is that it can be used as an equipment to educate, to forbid, and as the thickening of faith. Furthermore, pantang larang has some meaning related to the local wisdom. According to Sarmidi [32], pantang larang can be interpreted as restrictions which are conveyed by the previous generation which then have become wise words which contain local wisdom. Aslan [33] states that pantang larang in Malaysian culture basically contains local wisdom value, including politeness, mutual respect, cooperation, and disciplines.

Table 1. Pantang Larang which is contained in the Myth of Coastal Malay in West Borneo

\begin{tabular}{|c|c|c|c|}
\hline No. & Pantang Larang & Function & Meaning \\
\hline 1 & $\begin{array}{l}\text { Pantang Larang } \\
\text { when entering } \\
\text { forest }\end{array}$ & $\begin{array}{l}\text { 1. As a means to educate with a } \\
\text { purpose that the society can } \\
\text { maintain the culture sustainability } \\
\text { including maintaining forest } \\
\text { sustainability, nature, water, and } \\
\text { customs rules in the society } \\
\text { 2. An affirmation of tradition and } \\
\text { social rules which relatively } \\
\text { shapes a collective treatment of } \\
\text { Coastal Malay people in West } \\
\text { Borneo }\end{array}$ & $\begin{array}{l}\text { Pantang larang when } \\
\text { entering forest contains a } \\
\text { meaning of disciplines not } \\
\text { to damage the forest by } \\
\text { maintaining, conserving } \\
\text { and utilizing the natural } \\
\text { resources. }\end{array}$ \\
\hline & $\begin{array}{l}\text { Pantang Larang } \\
\text { to Go Outside the } \\
\text { House when Hot } \\
\text { Rain }\end{array}$ & $\begin{array}{l}\text { This pantang larang has a function to } \\
\text { scare children in order that they will } \\
\text { not sick because go outside the house } \\
\text { when it is raining. }\end{array}$ & \\
\hline 2. & $\begin{array}{l}\text { Pantang Larang } \\
\text { to laugh at a cat } \\
\text { when it is raining }\end{array}$ & It has a function as a means to educate & $\begin{array}{l}\text { Educating people to have } \\
\text { mutual respects to every } \\
\text { God's creation on earth. }\end{array}$ \\
\hline 3. & $\begin{array}{l}\text { Pantang Larang } \\
\text { to refuse an } \\
\text { invitation to have } \\
\text { a meal }\end{array}$ & $\begin{array}{l}\text { It is a means to educate with a purpose } \\
\text { to share with others }\end{array}$ & $\begin{array}{l}\text { It contains a meaning of } \\
\text { mutual respects. This } \\
\text { mutual respects attitude is } \\
\text { showed by the host's } \\
\text { attitude who offers for a } \\
\text { meal. Besides that, every } \\
\text { visitor whom is offered } \\
\text { for a meal is not allowed } \\
\text { to refuse the host's } \\
\text { invitation. }\end{array}$ \\
\hline 4. & $\begin{array}{l}\text { Pantang larang to } \\
\text { cut trees }\end{array}$ & $\begin{array}{l}\text { It is a means to educate children in } \\
\text { conserving the environment }\end{array}$ & $\begin{array}{l}\text { It means to conserve the } \\
\text { environment in order that } \\
\text { flood or other natural } \\
\text { disasters are not } \\
\text { happened. Pokok Jawi- } \\
\text { Jawi is tree that has strong } \\
\text { roots which can absorb } \\
\text { water well. }\end{array}$ \\
\hline
\end{tabular}


Since the ancestral era, pantang larang is a thing which is considered as sacred. According to Aslan [33], everything which is considered sacred and having magical values is a culture of ancient Malaysian ethnic civilization. At this modern era, Malaysian people as a society still believes those pantang larang because they believe if they leave their ancestors' culture, it will cause a disaster on their life. Malay people believe that pantang larang for the sake of soul safety, activities, and occupations [30]. The following are media which are used to support the storytelling activities:
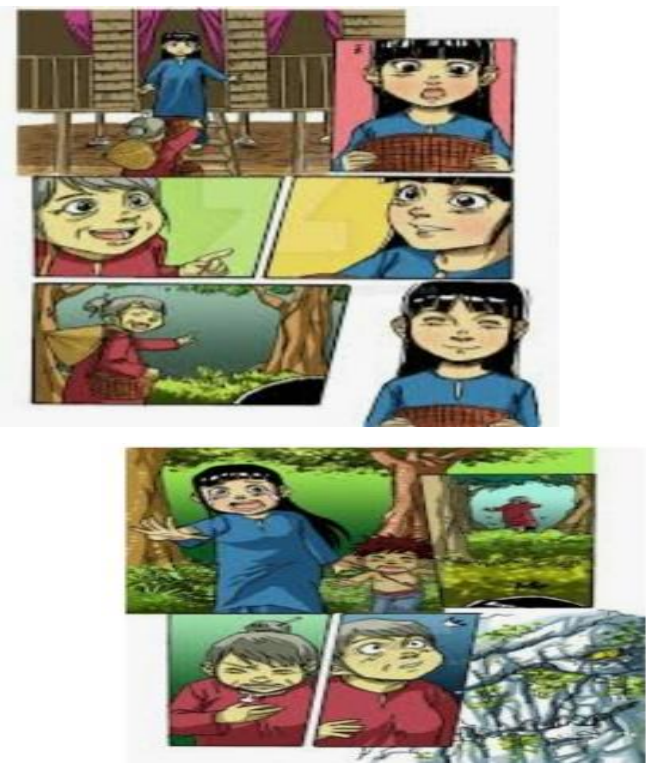

Pictures 2. Comics in digital, the works of Ashran (Malaysian Folk Tales)
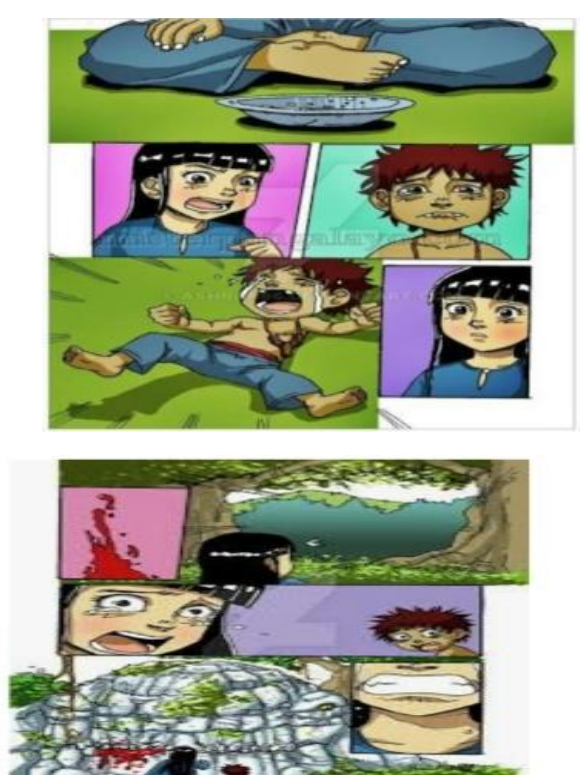

The above screenshot are some examples of folk tales of Coastal Malaysian in West Borneo entitled Batu Ballah Batu Betangkup which contains pantang larang it is not allowed to refuse if offered for eat or drink. The Coastal Malaysian people extremely believe that if they have been offered some drink of food, they do not touch the food (japai or jamah), they will get "kemponan". According to Wahab [34], if the host invites his friends for having some meals, at least the guest has to touch the meals. Kemponen is a designation for people who get disaster when someone wants to eat something but it can not be accomplished or someone is invited for having some meals, but he is not willing to have the meals. In the culture of Coastal Malaysian, people believe that he will get a disaster.

The development of communication technology has given some influences to the society's life so that it changes the way of interaction and communication which depends on the existence of visual media which also relates to digital story or digital storytelling. According to $\mathrm{Xu}$ [35], flexibility in the digital story refers to story creation which is not linear in using digital media technology. According to Fatmawati [26] there are four basic components in creating digital storytelling, including elements, media, process, and program. Furthermore, Fatmawati [26] explains that by using digital storytelling, the process of storytelling becomes deeper emotionally for parents or teachers. It is because the information from digital storytelling is more dynamic than from traditional storytelling. Its superiority is that children will be easier in 
understanding the content of the story because the presented display is in the form of audiovisual. On its implementation, digital storytelling uses some new technology or media. The use of sophisticated equipment, such as digital camera, headsets, video camera, crates (images, audio, video), put all together, share, and feedback. The following is a cycle of stages of digital storytelling process.

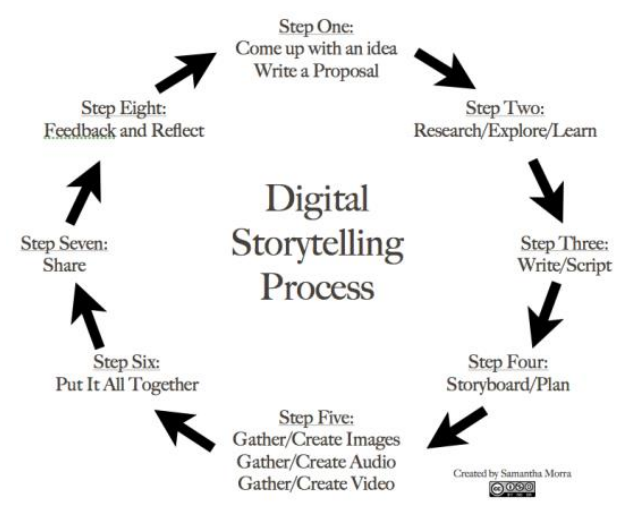

Picture 2. Digital Storytelling Process

Source: http://edtechteacher.org

Folklore is delivered through comics or movies as the communication media. The story is in the form of audio-visual illustration which involves the sense of sight and the sense of hearing. It is expected that children can catch the function and the meaning of pantang larang contained in the presented story.
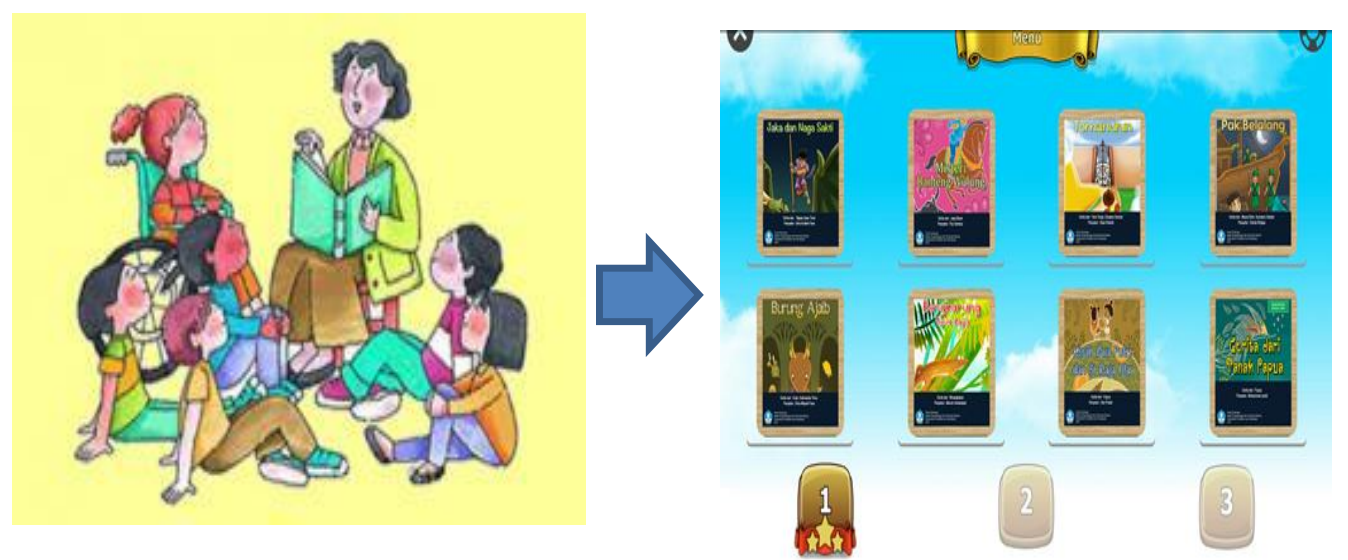

Picture 5. Traditional Storytelling to Digital Storytelling Source: Badan Pengembangan dan Pembinaan Bahasa Kemendikbud

The presence of electronic media equipment such as computer and smartphone is very helpful in reintroducing the function and the meaning of pantang larang contained in the folklores in order that the society especially children as the next generation can continuously 
conserve and maintain the national cultures. By the presence of digital storytelling as a media to tell a story, it can help people in reviving storytelling culture.

\section{Conclusion}

Based on the result of the analysis, there are five pantang larang in Coastal Malaysian myth in west Borneo, including 1) pantang larang when entering a forest, 2) going out of the house when hot rain, 3) laughing at a cat when it is raining, 4) rejecting invitation for having meal, and 5) cutting down Jawi-Jawi trees and killing crocodiles. These pantang larang have function as a means to educate children in order that they become obedient to their parents, respect to others, and love nature. Furthermore, pantang larang has a meaning for it society that is children have discipline, respects, shares with others, and do not damage the environment attitude. People of Coastal Malaysian in West Borneo consider that pantang larang has a special position. It is because pantang larang is believed containing supernatural powers. Pantang larang in the life of Coastal Malaysian society in West Borneo is used as the way of life in doing something because they believe if they violate this pantang larang, it will cause a disaster either for individual or society.

Communication technology, especially the application of digital storytelling is very important to be developed. Folklore which is packed in a digital form either comic, narration, or game will be very helpful for parents and teachers in reintroducing folklores to children. Folklore which is packed in digital storytelling form will attract children's interest to read a story because it is equipped with audio, pictures, music, and text which are packed in such a way, which are delivered through digital multimedia.

Acknowledgment. The writer wants to be thankful to Prof. Dr. Sarwiji Suwandi, M.Pd, Dr. Muhammad Rohmadi, M.Hum, and Dr. Nugraheni Eko Wardani, M.Hum, as the advisory team who have given some advice and suggestion for the improvement of content and linguistics aspects in this writing. The writer also says thank you to the informants who have given so many help in digging up the data of this study.

\section{References}

[1] R. O.-A. I. J. of E. L. and and undefined 2016, "Understanding the Classical Malay Literary Framework: A Reappraisal of the Poetic Theories of Vladimir Braginsky and Muhammad Haji Salleh," journals.iium.edu.my.

[2] S. J. Bronner, The Meaning of Folklore: The Analytic Essays of Alan Dundes. Longan Utah: Utah State Univesity Press, 2007.

[3] N. A. R.-T. O. J. of E. Technology and undefined 2014, "The Nearly Forgotten Malay Folklore: Shall We Start with the Software?.," ERIC.

[4] S. Zafar, \& S. S.-P. J. of S. S., and undefined 2014, "Resistance through Orality (and Silence) in Incidents in the Life of a Slave Girl, and Dessa Rose.," pertanika2.upm.edu.my.

[5] Z. Zinnatullina and L. Khabibullina, "The role of historical and religious components in john fowles's novel a maggot," dspace.kpfu.ru.

[6] J. J.-I. J. of E. A. and and undefined 2014, "Myths in African Concept of Reality.," ERIC.

[7] H. O.-S. (ATMA) and undefined 2008, "Conceptual understanding of myths and legends in Malay history," Citeseer.

[8] Y. B.-J. I. Komunikasi and undefined 2014, "Model komunikasi lintas budaya dalam 
resolusi konflik berbasis Pranata Adat Melayu dan Madura di Kalimantan Barat," jurnal.upnyk.ac.id.

[9] H. A. Wahab, "Petuah dan Pantang Larang Tradisional dalam Alam Melayu Serawak," Int. J. Malay World Civilis., vol. 1, no. 1, pp. 89-97, 2013.

[10] H. bin H. M. D. Mohtar, Kepercayaan dan Pantang-Larang. Malaysia: Federal Publication, 1977.

[11] \& T. N. Y.-P. J. of S. S. and undefined 2015, "Impact of Global and Chinese Cultural Values on Young People's Perceptions of Parenthood in Hong Kong, China.," search.ebscohost.com.

[12] G. Sarmidi, Keberadaan Wacana Pantang Larang Berlaras Gender Sebagai Tradisi Lisan, Fenomena Bahasa, dan Sastra Lisan di Indonesia. 2015.

[13] T. Haryadi, D. I.-A. J. Desain, and undefined 2016, "Penanaman Nilai dan Moral pada Anak Sekolah Dasar dengan Pendekatan Storytelling Melalui Media Komunikasi Visual," publikasi.dinus.ac.id.

[14] R. M. Anuar, M. S. A.-M. dan Masyarakat, and undefined 2014, "Kepercayaan kenan dalam masyarakat Melayu: Kajian dari perspektif hukum Islam,” eprints.um.edu.my.

[15] E. Syahrir, "Ungkapan Pantang Larang Masyarakat Melayu Belatik," J. Madah, vol. 7, no. 2, pp. 237-250, 2016.

[16] S. K.-T. J. of I. E. (Jurnal and undefined 2016, "Pantang Larang in the Sepinggan Village Muslim Community from the Perspective of Character Education," jurnal.radenfatah.ac.id.

[17] A. O.-M. J. A. D. MELAYU and undefined 2014, "Pantang larang dalam kalangan orang Melayu analisis dari perspektif teori SPB4K," ir.upsi.edu.my.

[18] A. H.-A. Indonesia and undefined 2013, "Makna Kultural Mitos dalam Budaya Masyarakat Banten," journal.ui.ac.id.

[19] J. Danandjaja, Folkloe Indonesia Ilmu Gosi, Dongeng, dan Lain-Lain. Jakarta: Grafiti Pres, 2007.

[20] H. Usman, "Mitos Harimau dalam Pengaturan Adat Masyarakat Kerinci Desa Pulau Tengah, Jambi, Sumatera," Int. J. World Civilsation, vol. 2, no. 3, pp. 99-109, 2014.

[21] H. Nuraini, S. Zuhri, and M. Ariyanto, "Makna Mitos Ritual Kungkum Di Umbul Sungsang Pengging Boyolali," 2011.

[22] S. Koki, Stortellyng: The Heart and Soul Education. Hawai'i: Press Pacific Resource for Education and Learning, 1998.

[23] U. A.-J. al-S. B. D. Konseling and undefined 2018, "Pengaruh Teknik Storytelling Terhadap Peningkatan Kreativitas Remaja," jurnal.uinbanten.ac.id.

[24] Y. Rahmawati, "Pengenalan Budaya Melalui Bercerita untuk Anak Usia Dini," J. Pendidik. Anak, vol. 1, no. 1, pp. 72-78, 2012.

[25] N. Dhieni, Metode Pengembangan Bahasa. Jakarta: Universitas Terbuka, 2008.

[26] E. Fatmawati, "Media Baru Digital Storytelling di Perpustakaan," J. Ilm. Kepustakawan "Libraria", vol. 4, no. 2, pp. 105-117, 2015.

[27] O. Dreon, R. M. Kerper, and J. Landis, "Digital Storytelling: A Tool for Teaching and Learning in the YouTube Generation," Middle Sch. J., vol. 42, no. 5, pp. 4-10, May 2011.

[28] J. Creswell, Research Design. Pendekatan, Kualitatif, Kuantitatif, and Mixed. Edisi Ketiga (Terjemahan). Yogyakarta: Pustaka Pelajar, 2010.

[29] Hamidy, Kamus Antropologi Diealek Melayu Rantau Kuantan Riau. Pekan Baru: Unri Perss, 1995.

[30] T. Effendi, Pandangan Orang Melayu Terhadap Anak. Pekan Baru: Lembaga Adat 
Daerah Riau, 1990.

[31] Sefridanita;Nurizzati;Zulfikarni, "Kategori dan Fungsi Sosial Ungkapan Kepercayaan Masyarakat Larang Pantang Calon Pengantin Perempuan di Nagari Barung-Barung Balantai Kecamatan Koto XI Tarusan Kabupaten Pesisir Selatan,” Universitas Negeri Padang, 2012.

[32] R. Sibarani, Kearifan Lokal Hakikat, Peran, dan Metode Tradisi Lisan. Jakarta: Asosiasi Tradisi Lisan (ATL), 2012.

[33] A. Aslan, "NILAI-NILAI KEARIFAN LOKAL DALAM BUDAYA PANTANG LARANG SUKU MELAYU SAMBAS,” J. Ilmu Ushuluddin, vol. 16, no. 1, p. 11, Jul. 2017.

[34] H. W. J. of the M. W. and and undefined 2013, "Petua dan Pantang Larang Tradisional dalam Alam Melayu Sarawak," journalarticle.ukm.my.

[35] Y. Xu, H. Park, Y. B.-J. of educational technology \& society, and undefined 2011, “A new approach toward digital storytelling: An activity focused on writing self-efficacy in a virtual learning environment," JSTOR. 